Volume 10 Nomor 2, April 2019, p.077-088

Faculty of Law, Universitas Kristen Maranatha

ISSN: 2085-9945 I e-ISSN: 2579-3520

Nationally Accredited Journal by SINTA

\title{
Akses Mendapatkan Keadilan (Access to Justice): Hak Konsumen Atas Alternatif Penyelesaian Sengketa di Luar Pengadilan
}

\section{Ai Permanasari}

\author{
Faculty of Law, Maranatha Christian University \\ aipermanasari@gmail.com
}

Submitted: 2019-04-22; Reviewed: 2019-04-25; Accepted: 2019-04-30

\begin{abstract}
Access to justice is a mechanism for every person, whose rights are violated, including consumers who are in dispute, to find effective solutions provided by the justice system. The mechanism shouldt be accessible, affordable and easy to understand. This mechanism must be able to provide justice fairly, speedy and without discrimination, and must also provide an alternative dispute resolution. In the case of consumer alternative dispute resolution outside the court, it should provide a great benefit to the community, because the avaibility of the choice to access justice in a way that can be adapted to their needs and abilities. But what is the meaning of the alternative or choice if in the end it cannot be implemented or cannot be executed to what has become decision or agreement of the alternative institution. This is related to the contradiction of the strength of BPSK decisions, in order there are still legal remedies against the BPSK decision, and the execution of the BPSK verdict still relies on the existence of 'fiat' executions from the court. Therefore to ensure access to justice for the consumers, harmonization between courts and consumer alternative disputes resolution system is unavoidable.
\end{abstract}

Keywords: Access to Justice; alternative dispute resolution; consumer rights

\section{PENDAHULUAN}

Akses kepada keadilan (access to justice) adalah nilai yang mendasari demokrasi, merupakan bukti adanya kedaulatan hukum yang mengatur (rule of law) di negara kita. Kesamaan atau kesetaraan akses pada keadilan merupakan hak asasi 
Volume 10 Nomor 2, April 2019

manusia, hal mendasar bagi terciptanya ketertiban dan kesejahteraan, dan jaminan atas partisipasi kita yang sah secara hukum dalam masyarakat. Akses mendapat keadilan fokus pada dua tujuan dasar dari sistem hukum. Sistem hukum, yaitu sistem dimana kita dapat mempertahankan hak kita dan menyelesaiakanperselisihan di bawah naungan Negara. Fokus pertama, bahwa sistem harus sama-sama dapat diakses oleh semua orang; kedua, bahwa sistem tersebut menghasilkan pemenuhan atas keadilan bagi individu dan masyarakat, yang mengindikasikan bahwa sistem tersebut juga harus berjalan efektif. ${ }^{1}$ Dimana proses hukum harus mampu menyelesaikan persoalan secara tuntas dan memberikan keadilan substantif bagi para pihak.

Untuk menjamin akses keadilan bagi semua lapisan masyarakat, maka sistem hukum harus terjangkau oleh masyarakat dan secara efektif keadilan tersebut dapat diklaim oleh masyarakat. Dalam hal akses pada keadilan melalui pengadilan yang dikenal mahal dan memakan waktu lama, maka harus ada solusi atau alternatif lain yang dapat menjamin akses keadilan masyarakat yang tidak memiliki cukup uang dan waktu untuk mencari keadilan di pengadilan. Sehingga kehadiran alternatif penyelesaian sengketa di luar pengadilan merupakan konsekuensi logis untuk menjamin akses terhadap keadilan tersebut. Namun apalah artinya alternatif tersebut jika pada akhirnya tidak dapat dilaksanakan atau tidak dapat dieksekusi apa yang menjadi hasil putusan maupun kesepakatan lembaga alternatif tersebut. Hal tersebut yang akan menjadi fokus pembahasan pada artikel ini, terutama di bidang perlindungan konsumen.

\section{PEMBAHASAN}

\section{Akses Kepada Keadilan dan Penyelesaian Sengketa di Luar Pengadilan}

Penghormatan dan perlindungan terhadap hak asasi manusia hanya dapat dijamin dengan ketersediaan pemulihan hukum yang efektif. Ketika suatu hak dilanggar atau dirusak, akses terhadap keadilan merupakan hal mendasar yang sangat penting bagi individu yang dilanggar haknya tersebut untuk mendapatkan pemulihan haknya, hal tersebut merupakan komponen penting dari keberadaan kedaulatan hukum (rule of law). ${ }^{2}$ Sejalan dengan definisi akses kepada keadilan yaitu, "as the ability of people to seek and obtain a remedy through formal or informal institutions of justice for grievances in compliance with human rights standards"3. Secara bebas dapat

\footnotetext{
1, Bryant G Garth and Mauro Cappelletti, Access to Justice: The Newest Wave in the Worldwide Movement to Make Rights Effective, Articles by Maurer Faculty, 1978, Paper 1142. http://www.repository.law.indiana.edu/facpub/1142

2 Francioni F, ed, Access to Justice as a Human Right, Oxford University Press, 2007. http://www.oxfordscholarship.com/view/10.1093/acprof:oso/9780199233083.001.0001/acprof9780199233083. Accessed April 10, 2019.

${ }^{3}$ United Nations Development Programme, Programming for Justice: Access for All: A Practitioner's Guide to a Human Rights-Based Approach to Access to Justice, Bangkok, UNDP, 2005.
} 
Volume 10 Nomor 2, April 2019

diartikan bahwa akses terhadap keadilan didefinisikan sebagai kemampuan seseorang untuk mencari dan memperoleh pemulihan haknya melalui lembaga peradilan formal atau informal atas kerugian akibat pelanggaran hak sesuai dengan standar hak asasi manusia. Gerakan "Access to Justice" (Akses kepada Keadilan) didasarkan pada gagasan bahwa sistem prosedur hukum dan aturan hukum harus sama-sama dapat diakses oleh setiap warga negara. Gerakan ini telah memberikan wawasan tentang bagaimana struktur dan institusi baik masyarakat maupun hukum mempengaruhi fungsi pengadilan dan bagaimana akses terhadap keadilan secara nyata seringkali lemah bagi banyak kelompok sosial. Kritik terhadap pendekatan tradisional normatif murni untuk prosedur masyarakat dalam mendapat keadilan adalah salah satu landasan gerakan ini. ${ }^{4}$

Dalam pergerakan akses kepada keadilan sendiri dikenal 3 gelombang pergerakan (three waves of access to justice movement). Alternatif Penyelesaian Sengketa termasuk kedalam 3 gelombang reformasi yang menggambarkan hambatan (obstacles) yang harus diatasi dalam gerakan "access to justice". Gelombang pertama, fokus kepada biaya dari peradilan dan kebutuhan akan bantuan hukum, gelombang kedua fokus pada gugatan kolektif dan terfragmentasi serta memanfaatkan pada tindakan kelompok (class action) untuk mengajukan gugatan, dan gelombang ketiga fokus pada penggunaan Alternatif penyelesaian sengketa (Alternative Dispute Resolution) untuk memberikan alternatif pada penyelesaian sengketa. ${ }^{5}$

Akses terhadap keadilan melingkupi segala jenis hambatan bagi masyarakat untuk memiliki cara praktis dan efektif untuk mewujudkan hak hukum mereka. Model tiga gelombang hanya merupakan garis besar pergerakan terhadap tantangan akses kepada keadilan. Selain kekurangan bantuan hukum, banyaknya tumpukan kasus, aturan yang formalistik dan kurangnya mekanisme yang tepat untuk kepentingan kolektif, terdapat masalah lain seperti: ketidaktahuan masyarakat tentang hak hukum atau prosedur yang mana yang dapat digunakan; hukum semakin tidak dapat diakses karena mungkin terlalu terperinci, atau terlalu teknis; dan adanya sistem yang tumpang tindih. ${ }^{6}$ Selain itu terdapat juga beberapa masalah mendasar tentang konsep keadilan yang kompleks ${ }^{7}$, dan secara hukum solusi yang "benar" saja mungkin tidak cukup memenuhi rasa keadilan para pihak. Keadilan bukan hanya

\footnotetext{
${ }^{4}$ Laura Ervo - Anna Nylund (eds.), The Future of Civil Litigation - Access to Courts and Courtannexed Mediation in the Nordic Countries, Springer, Cham 2014, Hal. 325-344.

${ }^{5}$ Cappelletti M, "Alternative dispute resolution processes within the framework of the worldwide access-to-justice movement", Modern Law Rev 56, 1993, Hal.283-284

${ }^{6}$ Rhode D, Access to justice, Oxford University Press, 2004, hlm. 3-23 dalam Laura Ervo - Anna Nylund, Op.Cit.

7 Terdapat berbagai jenis keadilan: diantaranya keadilan distributif, keadilan reparatif, keadilan retributif, keadilan prosedural, dan keadilan relasional.
} 
Volume 10 Nomor 2, April 2019

pertanyaan tentang siapa yang membayar apa, tetapi pertanyaan tentang proses untuk menemukan keadilan. ${ }^{8}$

Alternatif penyelesaian sengketa (APS) diluar pengadilan hanyalah salah satu cara dari berbagai cara untuk mencapai keadilan (access to justice). APS, secara sederhana, mengacu pada ide untuk mengekplorasi pilihan-pilihan yang dapat dimanfaatkan dalam penyelesaian masalah selain di jalur litigasi, khususnya dalam kasus-kasus di mana litigasi tampaknya bukan merupakan pilihan yang terbaik. Sehingga walaupun merupakan kritik terhadap sistem hukum peradilan tradisional yang terlalu mengandalkan pengadilan untuk menyelesaiakan sengketa dan mendapatkan keadilan, tapi harus diakui bahwa keberadaan APS di luar pengadilan tidak bisa serta merta menghilangkan fungsi pengadilan. Pada dasarnya untuk beberapa perkara tetap membutuhkan wewenang pengadilan atau kekuasaan kehakiman dalam memberikan keputusan, dan untuk alasan kebijakan publik, tidak dapat diputuskan dan diselesaikan di luar pengadilan. ${ }^{9}$ Mekanisme APS, oleh karena itu tidak dimaksudkan untuk menggantikan sistem peradilan tradisional, tetapi untuk melengkapinya dengan mengembangkan sistem manajemen perselisihan yang lebih canggih lagi. ${ }^{10}$

Pada dasarnya adanya APS merupakan alternatif atau pilihan, dimana akses kepada keadilan dapat diperkuat dengan memberikan masyarakat pilihan dan suara dalam memilih proses keadilan yang ingin ditempuh. Munculnya APS sebagai bagian gerakan akses kepada keadilan disebabkan pengadilan (litigasi) sebagai sistem peradilan tradisional dalam beberapa hal tidak dapat diandalkan untuk mencapai keadilan. Litigasi adalah proses yang sangat memakan waktu, dalam beberapa kasus malah dapat menyebabkan kerugian untuk para pihak, tidak hanya secara finansial, tetapi juga secara emosional dan bahkan fisik. ${ }^{11}$ Oleh karena itu, dari perspektif para pihak, litigasi bukanlah pilihan yang menyenangkan untuk mendapatkan keadilan. Target utama dari akses kepada keadilan dalam hal ini secara ringkas yaitu: untuk menghindari proses peradilan yang sangat panjang; tidak ada penundaan-penundaan dalam proses keadilan (dan dengan demikian mengurangi biaya dan ketidakpastian proses); membuat proses yang terjangkau; mengurangi kompleksitas dan; mendapatkan pengadilan yang adil untuk semua orang (para

\footnotetext{
${ }^{8}$ Deutsch M, Justice and conflict, The handbook of conflict resolution, 2nd edn, San Francisco, 2006, dalam Laura Ervo - Anna Nylund, Op.Cit.

${ }^{9}$ J-C Betancourt, Alternative Dispute Resolution (ADR) and Access to Justice: An Introduction, Chartered Institute of Arbitrators, 2017.

${ }^{10}$ Cf Frank E dan A. Sander, "Alternative Methods of Dispute Resolution: An Overview", University of Florida Law Review 1-2, 1985, Hal. 37; David U. Strawn, Dispute Management: How to End the Litigation Problem, New York: iUniverse, 2004, hlm.1- 172. Dalam Julio César Betancourt, Alternative Dispute Resolution (ADR) and Access to Justice: An Introduction.

${ }^{11}$ Cf David Trubek and others, "The Costs of Ordinary Litigation", UCLA Law Review, 1984, hlm. 72. See also Warren E. Burger, Isn't There a Better Way?, American Bar Association Journal 275, 1982, Hal. 68. Dalam Ibid.
} 
pihak, korban, serta terdakwa dalam kasus pidana). Sebenarnya targetnya adalah untuk memberikan setiap warga negara kesempatan untuk membela hak-haknya dan untuk mencapai hasil yang bermanfaat untuk pencari keadilan. ${ }^{12}$

Di Indonesia perkembangan APS dapat diambil dari tonggak dimana pada tahun 2004 berkumpul dua puluh delapan orang hakim dari beberapa pengadilan di sekitar Jakarta, yang dihadiri salah satunya oleh Mariana Sutadi dari Mahkamah Agung. Pertemuan tersebut membahas bahwa banyaknya sengketa bisnis muncul, namun muncul ketidak percayaan dari kalangan pengusaha terhadap pengadilan, yang mengecap pengadilan sebagai institusi yang kurang bisa dipercaya, dimana putusan pengadilan tidak sejalan dengan iklim investasi, dan beragam argumen lain yang intinya berkaitan dengan tingkat kepercayaan terhadap peradilan. ${ }^{13}$ Tingkat ketidakpercayaan itu bahkan lebih tinggi di bidang hukum pidana. Dengan ketidakpercayaan itulah, akhirnya keluar konsep untuk menyelesaikan sengketa di luar proses pengadilan. Kalaupun tetap melekat pada badan pengadilan, prosesnya di luar proses acara peradilan biasa. Alternatif Penyelesaian Sengketa adalah lembaga penyelesaian sengketa atau beda pendapat melalui prosedur yang disepakati para pihak, yakni penyelesaian di luar pengadilan dengan cara (i) konsultasi; (ii) negosiasi; (iii) mediasi; (iv) konsiliasi; dan (v) penilaian ahli. Setelah momen pertemuan tersebut, Indonesia memiliki Undang-Undang No. 30 Tahun 1999 tentang Arbitrase dan Alternatif Penyelesaian Sengketa dan perangkat hukum di Indonesia juga terus mengalami perkembangan berkaitan dengan APS. ${ }^{14}$

\section{Hak atas Alternatif Penyelesaian Sengketa Konsumen di Luar Pengadilan}

Hubungan antara Konsumen dan Pelaku Usaha memiliki potensi konflik atau sengketa dalam memenuhi hak dan kewajibannya masing-masing. Untuk melindungi hak para pihak dan mengurangi sengketa maka diperlukan suatu pengaturan oleh hukum. Perlindungan dan pengaturan hukum juga sangat diperlukan ketika sengketa telah terjadi dalam hubungan hukum para pihak, sehingga perlu adanya sistem hukum penyelesaian sengketa yang secara adil dapat menjamin terpenuhinya kepentingan hukum dari pihak-pihak yang bersengketa. Terdapat beberapa peraturan di Indonesia yg berkenaan dengan hubungan hukum konsumen dan pelaku usaha, diantaranya UU No. 8 Tahun 1999 tentang Perlindungan Konsumen (selanjutnya UUPK) dan UU No. 5 Tahun 1999 tentang Larangan Praktek Monopoli Dan Persaingan Usaha Tidak Sehat. ${ }^{15}$ Selain itu terdapat Penyelesaian sengketa yang

\footnotetext{
${ }^{12}$ Manon Schonewille, Access to Justice: Legal aid \& Alternative Dispute Resolution, Better Access to Justice in Turkey Conference, European Commission, 2009.

${ }^{13}$ Mys, Menyongsong Alternatif Penyelesaian Sengketa, Hukum Online, 28 September 2008 https://www.hukumonline.com/berita/baca/hol20211/menyongsong-alternatif-penyelesaian-sengketa

${ }^{14} \mathrm{Ibid}$

${ }^{15}$ Persaingan usaha tidak sehat pasti mengakibatkan konsumen dirugikan, oleh karena itu negara wajib melindungi konsumen dengan membuat perundang-undangan yang bertujuan mengatur
} 
Volume 10 Nomor 2, April 2019

diatur dalam Peraturan Otoritas Jasa Keuangan (POJK) Nomor 1/POJK.07/2013 Tahun 2013 tentang Perlindungan Konsumen Sektor Jasa Keuangan yang dikeluarkan oleh OJK sebagai lembaga yang membawahi sektor jasa keuangan baik perbankan maupun non bank. Peraturan-peraturan tersebut memberikan dampak positif bagi perlindungan konsumen, dimana hukum tidak hanya menguntungkan pelaku usaha saja, tetapi juga mempertimbangkan kepentingan konsumen.

Konsumen adalah pihak yang harus mendapat perhatian lebih dalam perlindungan hukum, dikarenakan kedudukan konsumen yang tidak seimbang, dipandang lebih lemah dibanding kedudukan pelaku usaha. Kedudukan yang lemah karena konsumen diposisikan sebagai objek dalam hubungannya dengan pelaku usaha, bukan sebagai subjek. ${ }^{16}$ Konsumen sebagai objek dijadikan sasaran aktifitas bisnis untuk meraup keuntungan yang sebesar-besarnya oleh pelaku usaha. Selain itu lemahnya kedudukan konsumen disebabkan karena kurangnya pengetahuan mengenai perlindungan konsumen, lemahnya kesadaran akan hak-haknya sebagai konsumen, lemahnya posisi tawar konsumen terhadap produsen dan lemahnya aturan hukum maupun lembaga hukum yang mengatur dan mengawasi hak-hak konsumen. ${ }^{17}$ Atas dasar kondisi tersebut, perlu adanya upaya melindungi kepentingan konsumen secara integratif dan komprehensif. Pada dasarnya hal tersebut juga yang menjadi landasan secara filosofis dibentuknya UUPK.

Dalam sengketa konsumen dan pelaku usaha memiliki akses terhadap keadilan, dimana UUPK menyediakan sejumlah alternatif penyelesaian. Sesuai Pasal 45 ayat (2) UUPK, alternatif penyelesaian sengketa dapat ditempuh melalui jalur pengadilan atau di luar pengadilan. Mekanisme penyelesaian sengketa di luar pengadilan dapat ditempuh melalui proses membuat pengaduan atau gugatan atas kerugian yang dilakukan pelaku usaha ke Badan Penyelesaian Sengketa Konsumen (BPSK) yang dipilih secara sukarela oleh para pihak yang bersengketa. Penyelesaian sengketa melalui BPSK berbentuk mediasi, konsiliasi, dan arbitrase. Manakala penyelesaian masalah melalui BPSK menemukan jalan buntu, maka penyelesaian atas masalah

persaingan antar pelaku usaha dan perlindungan kepada konsumen. Di banyak negara Institusi yang mengawasi persaingan usaha tidak sehat dan perlindungan konsumen dijadikan satu. Di Indonesia kedua hal tersebut di atas diatur dalam dua Undang-Undang yang berbeda. Untuk persaingan usaha tidak sehat diatur dalam UU No. 5 Tahun 1999 dengan judul Larangan Praktek Monopoli dan Persaingan Usaha Tidak Sehat. Institusi yang mengawasi dinamai Komisi Pengawas Persaingan Usaha (KPPU). Sedangkan untuk Perlindungan Konsumen di atur melalui UU No. 8 Tahun 1999 tentang Perlindungan Konsumen. Lembaga yang mengawasinya dinamakan Badan Perlindungan Konsumen Nasional (BPKN). https://presidentpost.id/2018/11/07/persaingan-usaha-tidak-sehatmerugikan-konsumen/

${ }^{16}$ Subjek bisa diartikan sebagai pelaku atau yang memiliki peran, sementara objek dapat diartikan sebagai sasaran. https://kbbi.kemdikbud.go.id/

${ }^{17}$ Denico Doly, "Upaya Penguatan Perlindungan Konsumen di Indonesia Terkait Kalusula Baku", Jurnal Negara Hukum: Vol. 3, No. 1, Juni 2012

https://jurnal.dpr.go.id/index.php/hukum/article/view/223/164 
tersebut dapat dilakukan di pengadilan, setelah disepakati oleh salah satu atau kedua belah pihak yang bersengketa.

Para pihak juga dapat memilih untuk menyelesaikan sengketanya di pengadilan umum. Gugatan atas kasus perlindungan konsumen melalui pengadilan dapat ditempuh melalui tiga cara yaitu, pertama dapat menggugat sendiri secara langsung; kemudian dapat menggugat secara class action oleh seseorang atau sejumlah orang mengatasnamakan kelompok yang merasa dirugikan oleh objek sengketa yang sama; dan cara ke tiga menggugat secara legal standing oleh lembaga yang memiliki keprihatinan kepada isu perlindungan konsumen. Lembaga swadaya masyarakat yang melakukan gugatan legal standing bermaksud agar pemerintah mengubah kebijakan-kebijakannya yang dinilai merugikan kepentingan konsumen. Selain ketiga jenis gugatan tersebut di atas, ada juga gugatan yang dikenal sebagai gugatan civil lawsuit, yaitu gugatan oleh seseorang atau sekelompok warga negara karena negara dianggap tidak sanggup melindungi kepentingan warga negaranya. ${ }^{18}$

Namun dalam menjamin akses terhadap keadilan, tidak cukup dengan hanya tersedianya lembaga peradilan dan lembaga alternatif penyelesaian sengketa konsumen sebagai sarana proses keadilan. Akses terhadap keadilan menyangkut juga efektifitas dari sistem tersebut sehingga keadilan dapat dicapai dengan adanya pemulihan hak dan hasil yang bermanfaat untuk para pihak. Jeremy Bentham yang merupakan pencetus sekaligus pemimpin aliran kemanfaatan menyebutkan bahwa "The aim of law is The Greatest Happines for the greatest number (kebahagiaan yang sebesar-besarnya untuk sebanyak-banyaknya orang). ${ }^{19}$ Salah atu tujuan hukum adalah, hukum dapat memberikan jaminan kebahagiaan kepada individu-individu, kemudian orang banyak. Hukum harus bermanfaat bagi masyarakat, dimana masyarakat dapat mengklaim pemulihan hak jika haknya tersebut di langgar, termasuk mendapat ganti rugi dalam hal adanya kerugian. Seperti suatu adagium hukum "a right is not a right without a remedy" (Ubi Jus Ibi Remedium) atau dimana ada hak, disana ada kemungkinan menuntut, memperolehnya atau memperbaikinya bilamana hak tersebut dilanggar. Hukum menjadi tidak bermanfaat dalam hal kurangnya akses kepada keadilan, keterlambatan respon dan proses mencapai keadilan, penyusunan undang-undang yang buruk, interpretasi peradilan yang saling bertentangan terhadap hukum dan mahalnya biaya untuk keadilan. Pada dasarnya untuk alasan apa pun, sistem hukum yang tidak memberikan secara efektif hak masyarakat maka menyangkal hak-hak masyarakat tersebut.

Dengan adanya alternatif penyelesaian sengketa konsumen di luar dan di dalam pengadilan seharusnya memberikan manfaat yang besar bagi masyarakat karena

\footnotetext{
${ }^{18}$ Arif Rahman, "Penyelesaian Sengketa Konsumen Melalui Badan Penyelesaian Sengketa Konsumen (BPSK) Kota Serang", AJUDIKASI: Jurnal Ilmu Hukum, Vol. 2 No. 1, Juni 2018. Hal. 21-42.

${ }^{19}$ H.R Otje Salman, S, Filsafat Hukum (Perkembangan \& Dinamika Masalah), Bandung: Refika Aditama, 2010, hlm. 44.
} 
adanya pilihan untuk mengakses keadilan dengan cara yang dapat disesuaikan dengan kebutuhan dan kemampuannya. Namun apalah artinya alternatif atau pilihan tersebut jika pada akhirnya tidak dapat dilaksanakan atau tidak dapat dieksekusi apa yang menjadi hasil putusan maupun kesepakatan lembaga alternatif tersebut, sehingga tidak ada manfaat untuk masyarakat. Hal ini terkait kontradiksi kedudukan BPSK yang keputusannya diragukan kekuatannya, karena masih terdapat upaya hukum keberatan pada putusan BPSK, serta pada pelaksanaan eksekusi putusan BPSK masih mengandalkan adanya 'fiat' eksekusi dari pengadilan.

Terkait kedua lembaga penyelesaian sengketa konsumen yang ada tersebut, dipertanyakan kesetaraannya dalam beberapa hal termasuk kewenangan dan kekuatan putusannya, dimana seharusnya mempunyai kekuatan yang sama. Sesuai dengan yang Pasal 54 ayat (3) UUPK dan Pasal 42 ayat (1) Kepmenperindag Nomor 350/2001, yang menyatakan bahwa putusan BPSK merupakan putusan yang final dan mengikat. Pengertian "final" berarti bahwa penyelesaian sengketa telah selesai dan berakhir, sedangkan kata "mengikat" mengandung arti memaksa dan sebagai sesuatu yang harus dijalankan oleh pihak yang diwajibkan untuk itu. Namun Pasal 56 ayat (2) UUPK memberikan jalan bagi pihak yang tidak menerima putusan BPSK, untuk mengajukan (keberatan) kepada Pengadilan Negeri. Hal tersebut bertentangan dengan pengertian putusan BPSK yang bersifat final dan mengikat, sehingga ketentuan pasal - pasal tersebut kontradiktif. Kekuatan putusan BPSK juga dilemahkan dengan banyaknya putusan BPSK yang dibatalkan oleh pengadilan.

Ketidaksetaraan juga terlihat bahwasanya untuk mengeksekusi putusan BPSK pun ternyata tidak cukup hanya mengharapkan itikad baik para pihak dalam menjalankan putusan. Menurut Pasal 57 UUPK, putusan majelis BPSK tetap harus dimintakan (fiat) eskekusi terlebih dahulu kepada pengadilan negeri di tempat tinggal konsumen. Sekalipun tidak ada "upaya hukum keberatan", tetap saja putusan majelis BPSK ini harus berurusan dengan lembaga pengadilan. Secara kontradiktif di satu sisi ada keinginan mempercepat eksekusi (tujuh hari kerja setelah pelaku usaha menerima putusan), tetapi di sisi lain ada keinginan untuk tetap melibatkan pengadilan negeri, yang akan membuat penyelesaian suatu kasus menjadi lebih lama. ${ }^{20}$ Seperti adagium hukum "Justice delayed is Justice denied", adalah pepatah hukum yang berarti bahwa jika ganti rugi secara hukum tersedia untuk pihak yang telah mengalami kerugian, tetapi tidak kunjung datang, secara efektif sama dengan tidak memiliki ganti rugi sama sekali. Prinsip ini adalah dasar untuk hak atas persidangan cepat (speedy trial) dan hak-hak serupa yang dimaksudkan untuk mempercepat sistem hukum, karena tidak adil bagi pihak yang dirugikan menunggu lama tanpa ada harapan terpenuhi hak-haknya. Mengingat salah satu alasan dicarinya

20 Shidarta, Badan Penyelesaian Sengketa Konsumen: Seberapa Gereget?, Jakarta:Universitas Bina Nusantara, November 2018, https://business-law.binus.ac.id/2018/11/05/badan-penyelesaiansengketa-konsumen-seberapa-greget/ 
alternatif penyelesaian sengketa di luar peradilan adalah untuk menjamin hak masyarakat untuk dapat mengakses keadilan, dimana lembaga pengadilan dianggap terlalu mahal, menyita banyak waktu dan sulit mendapat keadilan. Bagi jumlah kerugian yang kecil dalam sengketa konsumen dan pelaku usaha, tidak mungkin membawanya ke pengadilan, karena biaya pengadilan yang mahal akan menyebabkan ganti kerugian tidak akan sebanding dengan biaya perkara yang harus dikeluarkan. Alternatif penyelesaian sengketa konsumen di luar pengadilan merupakan pemerataan akses terhadap keadilan. Namun apalah artinya alternatif tersebut jika pada akhirnya tidak dapat dilaksanakan atau tidak dapat dieksekusi apa yang menjadi hasil putusan maupun kesepakatan lembaga alternatif tersebut, sehingga dengan begitu akan terhalangnya akses terhadap keadilan yang merupakan hak masyarakat.

Harmonisasi antara pengadilan dan sistem penyelesaian sengketa konsumen di luar pengadilan merupakan hal yang tidak dapat dihindarkan dalam menjamin akses terhadap keadilan masyarakat. Diawali dengan harmonisasi bidang hukum, dalam hal ini revisi UUPK dengan memperbaiki pasal-pasal yang saling berkonflik dalam hal kekuatan putusan BPSK tersebut. Penafsiran terhadap Pasal 54 ayat (3) UUPK dan Pasal 42 ayat (1) Kepmenperindag Nomor 350/2001, yang menyatakan bahwa putusan BPSK sebagai lembaga penyelesaian sengketa konsumen di luar pengadilan, merupakan putusan yang final dan mengikat menghadapi ketidakpastian hukum, dimana terhadap putusan BPSK yang final mengikat masih dapat diajukan upaya keberatan kepada Pengadilan, yang mana bisa berujung pada pembatalan putusan majelis BPSK tersebut oleh Pengadilan. Harmonisasi dapat menjadikan BPSK menjadi suatu lembaga alternatif penyelesaian sengketa yang mandiri, yang putusannya berkekuatan hukum final dan mengikat, dan melepaskan dari ketergantungan BPSK kepada pengadilan untuk fiat eksekusi agar putusan penyelesaian sengketa dapat dilaksanakan dengan efektif dan efisien.

Akses keadilan dalam penyelesaian sengketa dapat dicapai dengan memperhatikan asas cepat, sederhana, dan biaya ringan sebagaimana diatur dalam pasal 4 ayat (2) UU No. 4 tahun 2004 tentang Kekuasaan Kehakiman. Asas cepat dimaksudkan agar dalam penanganan perkara dapat diselesaikan dalam waktu yang singkat, sehingga tidak memakan waktu yang lama. Dalam suatu putusan yang cepat dan tepat terkandung keadilan yang bernilai lebih. Ketetapan putusan sesuai dengan hukum, kebenaran dan keadilan itu saja sudah mengandung nilai keadilan. Asas pengadilan yang cepat harus sampai pada kecepatan pelaksanaan putusannya, sehingga hak-hak para pihak dapat terpenuhi. Dimana dalam penundaan pemenuhan hak para pihak untuk mendapat haknya merupakan ketidakadilan (Justice delayed is Justice denied). Cepat, harus dimaknai sebagai upaya strategis untuk menjadikan sistem peradilan sebagai institusi yang dapat menjamin tercapainya keadilan dalam 
penegakan hukum secara cepat oleh pencari keadilan. ${ }^{21}$ Bukan hanya asal cepat terselesaikan saja yang diterapkan tapi pertimbangan yuridis, ketelitian, kecermatan, maupun pertimbangan sosilogis yang menjamin rasa keadilan masyarakat juga diperhatikan. Asas ini meliputi cepat dalam proses, cepat dalam hasil, dan cepat dalam evaluasi terhadap kinerja dan tingkat produktifitas institusi peradilan.

Kemudian perlu ditegaskan kompetensi BPSK, sehingga terdapat kepastian hukum atas kewenang BPSK dalam mengadili suatu perkara. Misalnya melalui banyak putusan, Mahkamah Agung (MA) sudah banyak mengoreksi kewenangan Badan Penyelesaian Sengketa Konsumen (BPSK) menyelesaikan sengketa perjanjian kredit kendaraan bermotor. Meskipun UU No. 8 Tahun 1999 tentang Perlindungan Konsumen memberi ruang kepada konsumen untuk membawa perkaranya dengan pelaku usaha ke BPSK, MA berpendapat sengketa konsumen yang bersumber dari perjanjian pembiayaan kendaraan bermotor bukan merupakan kewenangan BPSK, melainkan kewenangan peradilan umum. ${ }^{22}$ Kemudian dalam hal tumpang tindih kewenangan BPSK dan Lembaga Alternatif Penyelesaian Sengketa (LAPS) di sektor jasa keuangan yang mempunyai kewenangan yang sama dengan BPSK, belum ada kejelasan apakah sengketa yang terjadi antara konsumen dan Lembaga Jasa Keuangan dapat diselesaikan ke BPSK. Karena lagi-lagi banyak putusan BPSK yang dibatalkan oleh MA. Pertimbangan hukumnya adalah karena BPSK dinilai tidak memiliki wewenang untuk menyelesaikan sengketa di ranah jasa keuangan. ${ }^{23}$

\section{KESIMPULAN}

Akses kepada keadilan dapat dicapai tidak hanya dengan tersedianya mekanisme penyelesaian sengketa, tetapi memastikan bahwa mekanisme tersebut dapat berfungsi efektif. Dalam bidang perlindungan konsumen walaupun sudah terdapat alternatif penyelesaian sengketa di luar pengadilan yang dilaksakan oleh BPSK, namun dengan adanya kontradiksi kekuatan putusan BPSK menyebabkan pemulihan hak konsumen tidak dapat secara efektif dilaksanakan. Hal tersebut berarti akses kepada keadilan dibidang perlindungan konsumen masih terhalang. Untuk itu diperlukan adanya harmonisasi antara lembaga penyelesaian sengketa konsumen baik di dalam dan di luar pengadilan. Caranya bisa dengan revisi terhadap UUPK, terhadap pasal-pasal yang saling bertentangan, maupun dengan memperkuat dan memperjelas kedudukan kompetensi BPSK, sehingga terdapat kepastian hukum atas kewenang BPSK dalam mengadili suatu perkara.

\footnotetext{
${ }^{21}$ Sunaryo, Sidik, Kapita Selekta Sistem Peradilan Pidana, Malang: UMM Press, 2005, hlm. 47.

${ }^{22}$ Moh. Dani Pratama Huzaini, Ini Beleid Pemerintah yang Baru tentang BPSK, Hukumonline.com, 27 Pebruari 2018. https://www.hukumonline.com/berita/baca/lt5a94c7b618573/ini-beleid-pemerintahyang-baru-tentang-bpsk

${ }^{23}$ Fitri N. Heriani, LAPS atau BPSK Jika Terjadi Sengketa?, Hukumonline.com, 01 Maret 2018. https://www.hukumonline.com/berita/baca/lt5a9776ec8a39a/laps-atau-bpsk-jika-terjadi-sengketa
} 


\section{DAFTAR PUSTAKA}

\section{Buku}

Deutsch M, Justice and conflict, the handbook of conflict resolution, 2nd edn, San Francisco, 2006.

H.R Otje Salman, S, Filsafat Hukum (Perkembangan \& Dinamika Masalah), Bandung: PT. Refika Aditama, 2010.

Rhode D, Access to justice, Oxford University Press, 2004.

\section{Jurnal/Artikel}

Arif Rahman, Penyelesaian Sengketa Konsumen Melalui Badan Penyelesaian Sengketa Konsumen (BPSK) Kota Serang, AJUDIKASI: Jurnal Ilmu Hukum, Vol. 2 No. 1, Juni 2018.

Bryant G Garth and Mauro Cappelletti, Access to Justice: The Newest Wave in the Worldwide Movement to Make Rights Effective, Articles by Maurer Faculty, 1978, Paper 1142.

Cappelletti M, "Alternative dispute resolution processes within the framework of the worldwide access-to-justice movement", Modern Law Rev 56, 1993.

Denico Doly, "Upaya Penguatan Perlindungan Konsumen di Indonesia Terkait Kalusula Baku", Jurnal Negara Hukum: Vol. 3, No. 1, Juni 2012.

Fitri N. Heriani, LAPS atau BPSK Jika Terjadi Sengketa?, Hukumonline.com, 01 Maret 2018.

J-C Betancourt, Alternative Dispute Resolution (ADR) and Access to Justice: An Introduction, Chartered Institute of Arbitrators, 2017.

Laura Ervo - Anna Nylund (eds.), The Future of Civil Litigation - Access to Courts and Court-annexed Mediation in the Nordic Countries, Springer, Cham 2014.

Manon Schonewille, Access to Justice: Legal aid \& Alternative Dispute Resolution, Better Access to Justice in Turkey Conference, European Commission, 2009.

Moh. Dani Pratama Huzaini, Ini Beleid Pemerintah yang Baru tentang BPSK, Hukumonline.com, 27 Pebruari 2018. Mys, Menyongsong Alternatif Penyelesaian Sengketa, Hukum Online, 28 September 2008

Shidarta, Badan Penyelesaian Sengketa Konsumen: Seberapa Gereget?, Jakarta:Universitas Bina Nusantara, November 2018.

Sunaryo, Sidik, Kapita Selekta Sistem Peradilan Pidana, Malang: UMM Press, 2005.

United Nations Development Programme, Programming for Justice: Access for All: A Practitioner's Guide to a Human Rights-Based Approach to Access to Justice, Bangkok, UNDP, 2005. 
Dialogia luridica: Jurnal Hukum Bisnis dan Investasi

Volume 10 Nomor 2, April 2019

\section{Peraturan dan Perundang-Undangan}

Undang-Undang Nomor 8 Tahun 1999 tentang Perlindungan Konsumen

Undang-Undang Nomor 4 tahun 2004 tentang Kekuasaan Kehakiman

\section{Pranala Luar}

https://business-law.binus.ac.id/2018/11/05/badan-penyelesaian-sengketa-konsumenseberapa-greget/

https://jurnal.dpr.go.id/index.php/hukum/article/view/223/164

https://kbbi.kemdikbud.go.id/

https://presidentpost.id/2018/11/07/persaingan-usaha-tidak-sehat-merugikankonsumen/

https://www.hukumonline.com/ 